\title{
Między smokiem a jastrzębiem - rzecz o charakterze relacji amerykańsko-chińskich
}

\section{Wprowadzenie}

Blisko 40 lat temu Stany Zjednoczone Ameryki i Chińska Republika Ludowa nawiązały oficjalne stosunki dyplomatyczne, rozpoczynając "nowy etap" w relacjach dwustronnych. Postępująca od lat 80. XX wieku normalizacja stosunków amerykańsko-chińskich dała początek stabilnemu dialogowi politycznemu, dynamicznej współpracy handlowej, jak również regularnym konsultacjom w zakresie rozwiązywania problemów globalnych, szczególnie proliferacji broni masowego rażenia i zmian klimatycznych. Ewoluujące stosunki amerykańsko-chińskie nie są jednak wolne od licznych problemów i rozbieżności. Charakterystyczna dla relacji USA-Chiny jest ich niejednoznaczność. Deklarowane strategiczne partnerstwo obarczone jest wzajemną nieufnością. Strony wykazują sporą trudność w odczytywaniu szczerości intencji partnera. Amerykanie wątpią w chińską harmonijną (pokojową) współpracę, utrzymując, że Państwo Środka dąży do dominacji nad regionem Azji i Pacyfiku, z kolei Chińczycy uważają, że strategia USA ma na celu minimalizowanie udziału czynnika chińskiego na świecie.

Celem artykułu jest przybliżenie charakteru relacji łączących Stany Zjednoczone oraz Chiny, określenie czynników warunkujących współpracę amerykańsko-chińską, jak również tych, które powodują kontrowersje $\mathrm{w}$ relacjach dwustronnych i zbliżają państwa do konfrontacji. W artykule wykorzystano następujące metody badawcze: historyczną, ilościową, analizy oraz ekstrapolacji. Artykuł składa się z 4 części, mianowicie wprowadzenia, obszaru współpracy amerykańsko-chińskiej, obszaru rywalizacji 
amerykańsko-chińskiej oraz podsumowania. Tekst kończy wykaz bibliografii. Badania nad problematyką stosunków amerykańsko-chińskich prowadzone są przez liczne ośrodki naukowo-badawcze tak w Polsce, jak i zagranicą. Na gruncie polskich badań na szczególną uwagę zasługują prace Edwarda Haliżaka, Bogdan Góralczyka, Justyny Szczudlik, Katarzyny Hołdak oraz Przemysława Pacuły.

\section{Obszary współpracy}

Na przełomie lat 70. i 80 ubiegłego wieku Chiny rozpoczęły proces reform gospodarczych, które stały się początkiem budowy ekonomicznej potęgi Państwa Środka. Zapoczątkowana przez Denga Xiaopinga strategia otwarcia w stosunkach zewnętrznych doprowadziła do ogromnego wzrostu ekonomicznego, który w nowym tysiącleciu osiągnął dwucyfrowy wynik ${ }^{1}$. Dziś Chiny, obok Stanów Zjednoczonych, są najważniejszym podmiotem gospodarczym świata.

Normalizacja stosunków amerykańsko-chińskich, rozpoczęta od wizyty w Chinach prezydenta Richarda Nixona w lutym 1972 roku, umożliwiła państwom podjęcie współpracy gospodarczej. Pierwszą umowę handlową USA i Chiny podpisały 7 lipca 1979 roku, na mocy której Pekin otrzymał klauzulę największego uprzywilejowania, co oznaczało dostęp do amerykańskiego rynku na zasadach krajów należących do Układu Ogólnego w sprawie Ceł i Handlu. W 1980 roku Chiny zapewniły preferencyjne warunki dla napływu zagranicznych inwestycji bezpośrednich ze Stanów Zjednoczonych, a w 1984 roku dla transferu technologii i rozwoju handlu produktami high-tech ${ }^{2}$. Wymiana handlowa między 1979 a 1985 rokiem utrzymywała się na poziomie $20 \%{ }^{3}$. Pozytywnie kształtujące się relacje gospodarcze uległy pogorszeniu na skutek wydarzeń na Placu Tian’anmen. Stany Zjednoczone zawiesiły wówczas klauzulę największego uprzywilejowania, nałożyły sankcje na sprzedaż technologii wojskowej, jak również zrezygnowały ze spotkań organizowanych na najwyższym szczeblu. Przyczyniło się to do spadku

Za: data.worldbank.org/indicator/NY.GDP.MKTP.KD.ZG (dostęp: 21.05.2016).

2 T. Białowąs, M. Kąkol, Wymiana handlowa Stanów Zjednoczonych z Chinami w latach 1978-2008, [w:] Militarne i gospodarcze determinanty państwowości azjatyckiej, J. Marszałek-Kawa (red.), Toruń 2010, s. 298-299.

3 Za: Y. Qixiang, The United States, [w:] China's Foreign Trade, Z. Peiji, R.W. Huenemann (red.), Lantzville 1989, s. 80. 
wartości amerykańskiego eksportu do Chin z 5,8 mld dolarów w 1989 roku do 4,8 mld dolarów w 1990 roku$^{4}$.

Sytuacja uległa poprawie na początku lat 90 . XX wieku, po wyborach prezydenckich $\mathrm{w}$ USA wygranych przez Billa Clintona. Wymiana handlowa zaczęła rosnąć, co było niewątpliwie związane z wprowadzeniem w życie postanowień Rundy Urugwajskiej GATT, które zakazywały lub ograniczały możliwości stosowania $\mathrm{w}$ handlu międzynarodowym barier pozataryfowych $^{5}$. Przyjęcie Chin do Światowej Organizacji Handlu w 2001 roku dało kolejny asumpt do zacieśniania stosunków handlowych nie tylko z USA. Stany Zjednoczone wspierały chińskie aspiracje do WTO, zgodnie z założeniem, że integracja Państwa Środka z międzynarodowymi instytucjami handlowymi przyczyni się do dalszego rozwoju i stabilizacji Chin, a najważniejsze - utrwali jej otwartość i wolnorynkowy charakter ${ }^{6}$. Jest to element długofalowej strategii Stanów Zjednoczonych względem Chin, której celem jest ewolucja chińskiego systemu polityczno-gospodarczego, stworzenie zamożnego społeczeństwa, które stanie się bliższe amerykańskiemu.

Obecnie amerykańsko-chińskie stosunki handlowe, po blisko czterech dekadach, wskazują silne współzależności. Wartość amerykańsko-chińskiego handlu w 2014 roku wyniosła 591 mld dolarów - warto przypomnieć w tym miejscu, że państwa w 1979 roku zaczynały wymianę od 2 mld dolarów ${ }^{7}$. Aktualnie Chiny są drugim największym partnerem handlowym USA, natomiast USA jest pierwszym dla Chin ${ }^{8}$. Amerykańskie firmy w 2013 roku zainwestowały w ChRL w sumie 364 mld dolarów, natomiast chińskie firmy w Stanach Zjednoczonych między rokiem 2000 a czwartym kwartałem 2015 roku zainwestowały 62,9 mld dolarów9.

Wysoka dynamika wymiany handlowej między państwami nie jest jednak wolna od zagrożeń, szczególnie niebezpiecznych dla Stanów Zjednoczonych.

Jednym $\mathrm{z}$ istotniejszych problemów, z którymi mierzą się Stany Zjednoczone jest pogłębiający się deficyt handlowy, będący efektem nadwyżki importu

4 Za: T. Białowąs, M. Kąkol, op. cit., s. 299-300.

5 Ibidem, s. 300.

6 E. Haliżak, Stosunki amerykańsko-chińskie. Partnerzy czy rywale XX I wieku?, „Azja i Pacyfik" 2001, nr 4, s. 47.

7 Za: W. M. Morrison, China-U.S. trade issues, Congressional Research Center, 15.12.2015.

8 Top ten trading partners of the China mainland, ChinaDaily.com.cn, http://www.chinadaily.com.cn/bizchina/2014-02/19/content_17290565.htm (dostęp: 22.05.2016).

9 Tracking Chinese investment in the U.S., China Investment Monitor, http://rhg.com/ interactive/china-investment-monitor (dostęp: 22.05.2016). 
z Chin do USA nad amerykańskim eksportem do Chin. Wzrost deficytu rośnie w tempie $21 \%$ rocznie od czasu przystąpienia Chin do Światowej Organizacji Handlu $^{10}$. Wei Li twierdzi, że jedną z przyczyn dysproporcji w amerykańsko-chińskim bilansie handlowym jest różnica w strukturze gospodarek państw, jak również relacje kursowe pomiędzy yuanem a dolarem ${ }^{11}$. Dla Stanów Zjednoczonych sporym problemem jest stale zaniżany, pomimo aprecjacji, kurs chińskiej waluty. Według niektórych źródeł, kurs yuana jest zaniżany o około $15-40 \%{ }^{12}$. Sztucznie niedoszacowana chińska waluta powoduje niezwykle tani eksport chińskich towarów, z którym amerykańskim producentom jest bardzo trudno konkurować ${ }^{13}$. Pogłębiający się deficyt handlowy w relacjach amerykańsko-chińskich negatywnie odbija się na amerykańskim rynku pracy. Według R. Scotta, w latach 2001-2007 zatrudnienie w Stanach Zjednoczonych spadło o 2 mln 295 tys. ${ }^{14}$. Szczególnie odbiło się to na sektorze elektronicznym i komputerowym. Co więcej, zanotowano również spadek wynagrodzeń osób zatrudnionych w sektorze przemysłowym o około 19,4 mld dolarów (porównując je do sytuacji równowagi bilansu handlowego ${ }^{15}$.

Obok braku równowagi w amerykańsko-chińskim bilansie handlowym, drugim palącym problemem $w$ relacjach dwustronnych państw jest zadłużenie Stanów Zjednoczonych wobec Chin. Państwo Środka jest właścicielem amerykańskich publicznych i prywatnych papierów wartościowych, wliczając do nich m.in. papiery wartościowe skarbu państwa czy akcje kapitałowe. Jak wskazuje Wayne M. Morrison, Chiny prześcignęły w 2008 roku Japonię w ilości posiadania papierów wartościowych amerykańskiego skarbu państwa, których wartość w lipcu 2015 roku wyniosła 1,24 bln dolarów ${ }^{16}$. Tak znaczne zadłużenie Stanów Zjednoczonych w Chinach może w przyszłości stać się instrumentem nacisku rządu chińskiego na amerykański. Z drugiej strony, uwzględniając fakt, że dolary stanowią 70\% chińskich rezerw

10 Dane za: R. E. Scott, The China Trade Toll. Widespread wage suppression, 2 million jobs lost in the U.S., „Briefing Paper” 2008, nr 219, s. 4.

11 W. Li, China-U.S. Economic Relations and the Trade Imbalance Issue, [w:] China-U.S. Relations Transformed: Perspectives and Strategic Interactions, S. Zhao (red.), London-New York, s. 106-112.

12 Za: W. M. Morrison, China-U.S. Trade Issues, Congressional Research Service, Report for Congress, 31.03.2009, s. 13.

13 K. Dumbaugh, China-U.S. Relations: Current Issues and Implications for U.S. Policy, Congressional Research Service, Report for Congress, 14.06.2006, s. 18.

14 Za: R. E. Scott, The China Trade Toll, s. 1.

15 Ibidem, s. 16.

16 W. M. Morrison, China-U.S. Trade Issues, Congressional Research Service, Report for Congress, 15.12.2015, s. 17. 
walutowych, a eksport towarów do USA wyniósł w 2010 roku blisko 364 mld dolarów, próba wywołania zapaści gospodarczej w USA rykoszetem odbiłaby się na gospodarce Państwa Środka ${ }^{17}$.

Kontrowersyjną kwestię w relacjach amerykańsko-chińskich stanowi problem ochrony własności intelektualnej. Według amerykańskich kalkulacji, naruszanie przez Chiny amerykańskich praw autorskich oraz znaków handlowych kosztuje amerykańskie przedsiębiorstwa blisko 2,5 mld dolarów ${ }^{18}$. Największe straty ponoszą korporacje muzyczne i filmowe. Stany Zjednoczone, napominane przez rodzime przedsiębiorstwa, wielokrotnie podnoszą tę kwestię na licznych spotkaniach z chińskimi partnerami. Władze Chin zapewniają, że poczyniono wiele na rzecz ochrony własności intelektualnej, tym niemniej wskazują, że brakuje wyrafinowanych narzędzi, które efektywnie radziłyby sobie ze wszelkimi próbami naruszania praw autorskich czy znaków handlowych.

Bezpośredni związek $\mathrm{z}$ naruszeniami własności intelektualnej ma zagrożenie cybernetyczne emitowane przez Chiny. W 2013 roku Mandiant - amerykańska firma zajmująca się bezpieczeństwem informacyjnym - opublikowała raport, w którym udokumentowano 141 przypadków cybernetycznego szpiegostwa w 20 różnych, amerykańskich sektorach, którego źródłem miała być Chińska Armia Ludowo-Wyzwoleńcza ${ }^{19}$. Władze chińskie zaprzeczyły tezom opublikowanym w raporcie. Najczęściej celem szpiegostwa cybernetycznego padają korporacje zbrojeniowe oraz przemysłowe. Zdaniem Przemysława Pacuły, jest to pokłosiem zapóźnienia technologicznego Państwa Środka oraz ma związek $\mathrm{z}$ trudnościami w legalnym zakupie licencji oraz nowoczesnych technologii ${ }^{20}$.

W obliczu narastających problemów z zakresu szeroko pojętego szpiegostwa cybernetycznego, USA i Chiny powołały w 2013 roku U.S.-China Cyber Working Group, której zadaniem jest łagodzenie napięć powstających między państwami $\mathrm{w}$ dziedzinie bezpieczeństwa informacyjnego. Efektem współpracy było przyjęcie podczas wizyty Xi Jinpinga w Waszyngtonie w dniach 24-25 sierpnia 2015 roku tzw. Porozumienia Cybernetycznego. Stany Zjednoczone i Chiny zgodziły się w nim na: wymianę informacji oraz pomoc w przypadkach złośliwej działalności cybernetycznej, powstrzymywanie się od świadomego wspierania cybernetycznej kradzieży własności

17 P. Pacuła, Duopol 2020? Stan relacji amerykańsko-chińskich i perspektywy ich rozwoju, s. 44.

18 Za: K. Dumbaugh, China-U.S. Relations: Current Issues and Implications for U.S. Policy, s. 18.

19 W. M. Morrison, China-U.S. Trade Issues, s. 41.

20 Patrz: P. Pacuła, op. cit., s. 49. 
intelektualnej, promowanie właściwych zachowań w przestrzeni cybernetycznej oraz walkę z cyberprzestępczością ${ }^{21}$.

Stany Zjednoczone i Chińska Republika Ludowa odgrywają kluczową rolę w zakresie międzynarodowej współpracy na rzecz ograniczenia globalnego ocieplenia. Oba państwa wspólnie zużywają około 36\% światowej energii oraz emitują blisko $40 \%$ dwutlenku węgla, pochodzącego z użycia paliw kopalnych $^{22}$. Nacisk społeczności międzynarodowej zaktywizował Chiny i USA do podjęcia dwustronnej współpracy celem ograniczenia emisji gazów cieplarnianych. Od 2006 roku USA i Chiny współpracują w ramach Dialogu Strategiczno-Ekonomicznego, który wypracował dziesięcioletni „Program Ramowej Współpracy w zakresie Energii i Środowiska”. Państwa w ramach tego programu zobowiązały się do podjęcia kooperacji w pięciu priorytetowych obszarach tj.: produkcji energii, transporcie, czystej wodzie, czystym powietrzu, ochronie terenów podmokłych i innych obszarów naturalnych oraz energii odnawialnej. Szczególnie obiecująca wydaje się współpraca państw w obszarze odnawialnych źródeł energii. Stany Zjednoczone posiadają bogate doświadczenie w dziedzinie energii odnawialnej zaliczając do niej: wiatr, słońce, biomasę i źródła geotermalne, którym mogą dzielić się z chińskimi partnerami, coraz bardziej zainteresowanymi tą formą pozyskiwania energii, by tylko zwrócić uwagę, że w ostatnich latach Chiny stały się największym światowym odbiorcą paneli słonecznych oraz kolektorów słonecznych ${ }^{23}$.

W sierpniu 2015 roku USA i Chiny przyjęły wspólne stanowisko dotyczące zmian klimatycznych i pogląd na nadchodzący Szczyt Klimatyczny w Paryżu. Waszyngton zobowiązał się do obniżenia emisji gazów cieplarnianych o 26-28\% do 2025 roku w stosunku do 2005 roku, Pekin natomiast zobowiązał się do redukcji emisji od 2030 roku i „uczynienia wszystkiego co w ich mocy", by szczyt emisji przypadł przed $2030^{24}$. Państwa uznały konieczność pogłębiania współpracy w ramach funkcjonującej U.S.-China Climate Change Working Group, promowanie odnawialnych źródeł energii oraz

21 J. W. Rollins, U.S.-China Cyber Agreement, CRS Insight, 06.10.2015, s. 1.

22 M. T. Cooke, Sustaining U.S.-China Cooperation in Clean Energy, Wilson Center, https://www.wilsoncenterokuorg/sites/default/files/US_China\%20Cooperatin\%20 in\%20Clean\%20Energy.pdf (dostęp: 26.05.2016).

23 Strengthening U.S.-China Climate Change and Energy Engagement - Recommendations for Leaders and Policymakers in the U.S. and China, https://www.nrdc.org/sites/ default/files/int_09021801a.pdf (dostęp: 26.05.2016).

24 J. P. Meltzer, U.S.-China Joint Presidential Statement on Climate Change: The Road to Paris and Beyond, http://www.brookings.edu/blogs/planetpolicy/posts/2015/09/ 29-us-china-statement-climate-change-meltzer (dostęp: 26.05.2016). 
wyasygnowanie dodatkowych środków finansowych na rzecz krajów rozwijających się, aby mogły wziąć odpowiedzialność za globalne ocieplenie ${ }^{25}$.

Obszar nauki jest kolejnym, w którym dostrzegalna jest ożywiona współpraca amerykańsko-chińska. W roku akademickim 2014/2015 w Stanach Zjednoczonych studiowało 304040 tys. chińskich studentów, którzy stanowili 31,2\% ogólnej liczby zagranicznych studentów uczących się na amerykańskich uczelniach ${ }^{26}$. W Chinach z kolei, w roku akademickim 2013/2014 uczyło się 13,763 tys. amerykańskich studentów ${ }^{27}$.

Współczesne stosunki amerykańsko-chińskie są niezwykle intensywne. Państwa współpracują na wielu płaszczyznach, od politycznej po kulturową. Istnieją także liczne programy kooperacji miast, prowincji i stanów ${ }^{28}$, co zbliża państwa na poziomie lokalnym. USA i Chiny utrzymują stałe kontakty na najwyższym szczeblu m.in. w ramach Dialogu Strategiczno-Ekonomicznego, współpracy na forach licznych organizacji międzynarodowych, zwłaszcza Rady Bezpieczeństwa ONZ oraz szeregu innych, globalnych i regionalnych instytucji.

\section{Obszary rywalizacji}

Stany Zjednoczone oraz Chińska Republika Ludowa są najważniejszymi podmiotami współczesnych stosunków międzynarodowych ${ }^{29}$. Oba państwa zaliczane są do mocarstw globalnych, mających potężną siłę oddziaływania w różnych obszarach życia międzynarodowego. Zarówno USA, jak i Chiny posiadają silne międzynarodowe aspiracje, które popychają je w kierunku rywalizacji.

W ciągu ostatnich lat zauważalny jest wzrost aktywności i asertywności Chińskiej Republiki Ludowej w kontekście jej zaangażowania na świecie, jak i udziału w międzynarodowych instytucjach (globalnych i regionalnych) ${ }^{30}$. Stało się to szczególnie widoczne w momencie objęcia stanowiska Przewodniczącego Chińskiej Republiki Ludowej przez Xi Jinpinga, który zrezygnował

25 Na podstawie: U.S.-China Joint Presidential Statement on Climate Change, https:// www.whitehouse.gov/the-press-office/2015/09/25/us-china-joint-presidential-statement-climate-change (dostęp: 26.05.2016).

26 International Students in the United States, http://www.iie.org/Services/Project-Atlas/ United-States/International-Students-In-US\#.V0b38OSbIwA (dostęp: 26.05.2016).

27 U.S. students studying overseas, http://www.iie.org/en/Services/Project-Atlas/United -States/US-Students-Overseas\#.V0b4DuSbIwA (dostęp: 26.05.2016).

28 E. Haliżak, op. cit., s. 45.

29 R. Foot, A. Walter, China, the United States, and Global Order, New York 2011.

30 M. Cox, The USA, China and the rising Asia, [w:] U.S. Foreign Policy, M. Cox, D. Stokes (red.), New York 2012, s. 259-274. 
z idei propagowanej przez Jiang Zemina: „działaj zgodnie z aktualną sytuacją, aby maksymalizować swoje zyski - na rzecz tworzenia sprzyjających międzynarodowych warunków, aby osiągać maksymalne zyski”31.

Chiny swoją ekstensywną politykę międzynarodową rozpoczęły od uregulowania stosunków dwustronnych z państwami sąsiednimi, z którymi obecnie współpracują w wielu dziedzinach od gospodarczej, przez polityczną, na społeczno-kulturowej skończywszy. Pekin uczestniczy w wielu regionalnych formatach m.in. w ASEAN i EAS, co wzmacnia stosunki wielostronne i prowadzi do wielu wymiernych korzyści, by tylko zwrócić uwagę na podpisanie w listopadzie 2004 roku „Porozumienia o Wolnym Handlu między Chinami a państwami ASEAN".

Chiny znormalizowały relacje dwustronne z państwami, z którymi łączyła je trudna przeszłość historyczna. 24 stycznia 2005 roku rozpoczęto Dialog Strategiczny z Indiami, którego efektem było m.in. przyjęcie Memorandum of Understanding Between the Ministries of Defence of China and India Regarding Interaction and Cooperation in the Area of Defence, w ramach którego państwa uczestniczyły we wspólnych ćwiczeniach antyterrorystycznych. Poprawie uległy także stosunki chińsko-japońskie, szczególnie w obszarze handlu, czego dowodem jest prześcignięcie przez Chiny USA w byciu największym partnerem handlowym Japonii.

Państwo Środka prowadzi ścisłą kooperację z Federacją Rosyjską, zwłaszcza w obszarze gospodarczym, jak również bezpieczeństwa energetycznego oraz militarnego. Pekin należy do największych importerów rosyjskiego uzbrojenia, choć jak podaje Sztokholmski Międzynarodowy Instytut Badań nad Pokojem w 2007 roku nastąpił spadek zakupów o 62\%, co może być spowodowane wzrostem chińskich możliwości produkcyjnych w tym obszarze $^{32}$. Niemniej jednak, Chiny uważają Federację Rosyjską za „głównego partnera strategicznej kooperacji”"33, czego wyrazem było zorganizowanie, po raz pierwszy w historii Państwa Środka, konsultacji chińsko-rosyjskich w dziedzinie bezpieczeństwa narodowego.

Chiny realizują od 2000 roku ofensywną politykę na kontynencie afrykańskim. Afryka jest istotna dla Chin z powodu występowania tam tanich surowców energetycznych, tak potrzebnych dynamicznie rozwijającej się

31 S. Simon, 10 Characteristics of Chinese diplomacy in the Xi Jinping era, http://foreignpolicyblogs.com/2016/04/19/10-characteristics-of-chinese-diplomacy-in -the-xi-jinping-era/ (dostęp: 28.05.2016).

32 Za: K. Dumbaugh, China's Foreign Policy: What does it mean for U.S. global interests?, Congressional Research Service, Report for Congress, 08.07.2008, s. 19.

33 Za: Idem, China-U.S. Relations: Current Issues and Implications for U.S. Policy, s. 15. 
chińskiej gospodarce. Chińczycy w odróżnieniu od Amerykanów nie mają problemu z rozwijaniem współdziałania z państwami autorytarnymi, stąd tak silna obecność czynnika chińskiego w Afryce. Współpraca chińsko-afrykańska jest wpisana w realizowaną od lat przez Państwo Środka formułę win-win. Chińczycy uzyskują wiele koncesji na wydobycie ropy naftowej czy żelaza, w zamian udzielając rządom poszczególnych państw afrykańskich kredytów oraz budując $w$ nich potrzebną infrastrukturę ${ }^{34}$. Negatywnym efektem działalności Chin na obszarze kontynentu afrykańskiego jest wykupywanie przez Pekin dużych obszarów pól uprawnych, co w przyszłości prawdopodobnie przyczyni się do zwiększenia zagrożenia głodu w Afryce ${ }^{35}$.

Równie dynamiczna co w Afryce jest aktywność Chin w Ameryce Łacińskiej i Karaibach. W 2005 roku Chiny podpisały Umowę o Wolnym Handlu z Chile, mając nadzieję, że stanie się ona wzorem dla podobnych umów z innymi państwami latynoamerykańskimi ${ }^{36}$. ChRL intensywnie współpracuje $\mathrm{z}$ Wenezuelą oraz Brazylią $\mathrm{w}$ zakresie pozyskiwania surowców energetycznych. W styczniu 2005 roku podczas wizyty w Chinach prezydenta Wenezueli Hugo Chaveza, podpisane zostało porozumienie, na mocy którego China National Petroleum Coorporation uzyskała możliwość wydobywania w tym kraju ropy naftowej oraz gazu ziemnego.

Prowadzona na wielu frontach międzynarodowa aktywność Państwa Środka stanowi wyzwanie dla Stanów Zjednoczonych, które od czasu zakończenia zimnowojennej konfrontacji pozostają światowym supermocarstwem. Koncentracja Waszyngtonu na Iraku i Afganistanie w okresie prezydentury George’a W. Busha znacznie osłabiła udział czynnika amerykańskiego w regionie Azji i Pacyfiku. Rosnąca potęga Chin w obszarze azjatyckim - strategicznie ważnym dla USA - wymusiła na Waszyngtonie dokonanie redefinicji międzynarodowej strategii.

„Zwrot ku Azji” zaproponowany w 2011 roku przez administrację Baracka Obamy miał na celu zmniejszenie oddziaływania czynnika chińskiego $\mathrm{w}$ regionie, poprzez wzmacnianie dwustronnych sojuszy z państwami regionu Azji i Pacyfiku, przede wszystkim Japonią, Koreą Południową, Filipinami, Australią oraz Nową Zelandią, pogłębianie współpracy w ramach azjatyckich organizacji regionalnych ze szczególnym uwzględnieniem ASEAN, zwiększanie wymiany handlowej i inwestycji, stałej obecności militarnej

34 Patrz: P. Pacuła, op. cit., s. 47.

35 Ibidem.

36 J. Wei, China-Chile FTA Talks Smooth, „Daily China”, 29.01.2005, http://www.chinadaily.com.cn/english/doc/2005-01/29/content_413383.htm (dostęp: 28.05.2016). 
w regionie oraz promocję demokracji ${ }^{37}$. Trwałym celem Waszyngtonu w regionie Azji i Pacyfiku, jak i innych obszarach świata, pozostaje ochrona interesów ekonomicznych, jak również kształtowanie polityki innych państw, tak aby pozostawały one $\mathrm{w}$ mniejszym lub większym stopniu w amerykańskiej strefie wpływów ${ }^{38}$.

W listopadzie 2011 roku Barack Obama wcielił w życie decyzję o wsparciu dwóch wielostronnych organizacji regionalnych - po pierwsze Partnerstwa Trans-Pacyficznego (TPP), które ma w przyszłości stanowić obszar wolnego handlu między Australią, Brunei, Kanadą, Chile, Japonią, Malezją, Meksykiem, Nową Zelandią, Peru, Singapurem, Wietnamem oraz Stanami Zjednoczonymi, a po drugie Szczytu Państw Azji Wschodniej (EAS), do którego USA przystąpiło w 2011 roku i dąży do wzmocnienia udziału tej organizacji $\mathrm{w}$ rozwiązywaniu regionalnych problemów z zakresu bezpieczeństwa.

Z chińskiej perspektywy szczególne zagrożenie budzi powstanie w jej bezpośrednim sąsiedztwie Partnerstwa Trans-Pacyficznego, które postrzegane jest jako celowe dążenie do ograniczenia obecności i siły oddziaływania Chin w regionie Azjii Pacyfiku, a wręczizolowania ich naarenie międzynarodowej.Stany Zjednoczone twierdzą, że obawy Chińczyków są nieuzasadnione. W grudniu 2014 roku prezydent Barack Obama powiedział, że „Stany Zjednoczone nie dążą do działania na niekorzyść Chin, więcej - życzą sobie, aby Chiny dołączyły do TPP nie jako formalny członek, ale państwo, któremu bliskie są dobre i sprawiedliwe praktyki" 39 .

Niepokój Chin budzi wzrost militarnej obecności USA w regionie Azji i Pacyfiku. Stany Zjednoczone posiadają bazy wojskowe w Japonii, Korei Południowej, Singapurze oraz Australii, gdzie został zwiększony amerykański kontyngent o dodatkowe 2,5 tys. żołnierzy. USA rozwija także współpracę wojskową z mniejszymi państwami azjatyckimi m.in. Filipinami, Kambodżą, Malezją, Indonezją oraz Wietnamem. Strategia ta budzi naturalny opór we władzach Pekinu.

37 Na podstawie: P. C. Saunders, To Rebalance to Asia: U.S.-China Relations and Regional Security, „Strategic Forum”, sierpień 2013, nr 281, s. 1; M. S. Indyk, K. G. Liberthal, M. E. O’Hanlon, Zmieniając historię. Polityka zagraniczna Baracka Obamy, Warszawa 2013, s. 24-64; J. Szczudlik-Tatar, China's Response to the United States' Asia-Pacific Strategy, „Policy Paper”, październik 2012, nr 41, s. 1-8; J. Tomaszewski, Zmiany w polityce bezpieczeństwa USA, „Bezpieczeństwo Narodowe” 2012, nr 3-4, s. 91-115.

M. Cox, op. cit., s. 273.

39 Za: B. R. Williams, B. Dolven, I. F. Fergusson, M. E. Manyin, M. F. Martin, W. M. Morrison, The Trans-Pacific Partnership: Strategic Implications, Congressional Research Service, Report for Congress, 03.02.2016, s. 11. 
Chiny pozostają wysoce krytyczne wobec polityki USA wobec Tajwanu, który pozostaje objęty amerykańskimi gwarancjami bezpieczeństwa na wypadek chińskiej agresji. Pekin twardo sprzeciwia się sprzedaży nowoczesnego, amerykańskiego uzbrojenia na rzecz Tajpej, oskarżając Amerykanów o destabilizowanie stosunków chińsko-tajwańskich i celowe podsycanie nastrojów secesjonistycznych. Podobny schemat uruchamiają Stany Zjednoczone, kiedy to chińskie uzbrojenie trafia do Teheranu, wówczas to Chiny stają się źródłem zakłóceń ładu międzynarodowego.

Choć Stany Zjednoczone pozostają globalną potęgą militarną, to nawet dla tego państwa zagrożeniem staje się stały wzrost wydatków obronnych Chińskiej Republiki Ludowej. Okazuje się, że chińskie wydatki zbrojeniowe rosną wraz z tempem gospodarczego rozwoju tego państwa. Według danych Sztokholmskiego Międzynarodowego Instytutu Badań nad Pokojem, Chiny w 2014 roku przeznaczyły na zbrojenia 216 mld dolarów, Stany Zjednoczone - dla porównania - wydały 610 mld dolarów ${ }^{40}$. Zdaniem Henry’ego Kissingera, rozbudowa chińskiego potencjału militarnego jest naturalnym procesem, zważywszy na otoczenie geopolityczne Państwa Środka, jak i dążenie do przełożenia sukcesu gospodarczego na zwiększone możliwości militarne ${ }^{41}$.

Wpływ na powstające $\mathrm{w}$ relacjach amerykańsko-chińskich kontrowersje mają także odmienne systemy polityczno-społeczne, uwarunkowania historyczno-kulturowe, ideologia i religia. Amerykanów i Chińczyków znacznie odróżnia hierarchia wyznawanych wartości. Dobitnie różnice te zostały pokazane w badaniu przeprowadzonym przez D. I. Hitchococka, z którego wynika, że najbardziej cenionymi wartościami wśród Azjatów są: porządek społeczny, dobra harmonia w społeczeństwie oraz zapewnienie odpowiedzialności funkcjonariuszy publicznych, natomiast dla Amerykanów jest to wolność wypowiedzi, prawa jednostki oraz wolności osobiste ${ }^{42}$.

40 Za: S. Pero-Freeman, A. Fleurant, P. D. Wezeman, S. T. Wezeman, Trends in World Military Expenditure, 2014, „SIPRI Fact Sheet”, April 2015, http://books.sipri.org/files/FS/SIPRIFS1504.pdf (dostęp: 28.05.2016).

${ }^{41}$ Henry Kissinger o przyszłości stosunków amerykańsko-chińskich, http://www.usa-eu. krakowskie.nazwa.pl/index.php?option=com_content\&view=article\&id=314:henry-kissinger-o-przyszoci-stosunkow-amerykasko-chiskich\&catid=17:przegld\&Itemid=13 (dostęp: 28.05.2016).

42 M. Kosmala-Kozłowska, Dwie cywilizacje. Dwa systemy wartości. Dwie wizje praw człowieka, [w:] Jednostka i społeczeństwo w Azji Wschodniej, A. W. Jelonek (red.), Torun 2007, s. 65; Y. Pan, W. R. Vanhonacker, Chinese and American Cultures: Value Structure and Family Orientation. An Explorative Study, Euro-Asia Centre Research Series, September 1992. 
Choć to rywalizacja geopolityczna powoduje największe napięcia w stosunkach amerykańsko-chińskich zwrócić należy uwagę, że strony są w stanie kontrolować powstające między nimi rozbieżności. W obliczu sytuacji kryzysowych zachowują się w sposób odpowiedzialny, unikają eskalacji problemu, co świadczy o dojrzałości państw i stabilnych relacjach amerykańsko-chińskich.

\section{Podsumowanie}

Stosunki amerykańsko-chińskie charakteryzuje wysoka dynamika i wielopoziomowość. Państwa prowadzą intensywny dialog polityczny, wsparty regularnymi wizytami najważniejszych przedstawicieli państwowych, jak również rozwijają kontakty na poziomie lokalnym, co jest szczególnie istotne dla chińskiej diaspory żyjącej w Stanach Zjednoczonych. USA i Chiny łączy niemalże symbiotyczna współzależność gospodarcza. Obszar współpracy ekonomicznej jest najszybciej i najbardziej dynamicznie rozwijającym się polem amerykańsko-chińskiej kooperacji. Choć amerykańsko-chińskie stosunki handlowe nie są wolne od kontrowersji, to stopień uzależnienia obu gospodarek sprawia, że i Chiny, i USA nie będą dążyły do pogłębienia rozbieżności. W interesie Waszyngtonu jest potrzeba finansowania amerykańskiego długu przez Chińczyków, natomiast $\mathrm{w}$ interesie Pekinu pozostaje potrzeba importu amerykańskich, nowoczesnych technologii, inwestycji, czy szerzej udziału w tamtejszym rynku; zatem spoiwem relacji amerykańsko-chińskich pozostaje obszar gospodarczy.

Z drugiej strony immanentną cechą stosunków amerykańsko-chińskich jest skłonność do rywalizacji - oba państwa dążą do odgrywania wiodącej roli we współczesnych stosunkach międzynarodowych, umacniania swojego wpływu politycznego/gospodarczego/militarnego/kulturowego $\mathrm{w}$ różnych regionach świata. Silne ambicje występujące zarówno w Waszyngtonie, jak i w Pekinie, tym bardziej motywują państwa do wzmożonej aktywności zewnętrznej. W sytuacji kolizji interesów strony zachowują pragmatyzm i nie dążą do pogłębiania kontrowersji, a już na pewno nie do konfliktu. Wydaje się bardzo mało prawdopodobne, aby państwa weszły na drogę otwartej, zbrojnej rywalizacji, nawet w kontekście tak newralgicznej kwestii, jaką dla obu podmiotów jest casus Tajwanu.

Specyfika relacji amerykańsko-chińskich pozwala domniemywać, że państwa - dziś najważniejsi aktorzy sceny światowej - będą kontynuowały współpracę: w obszarze gospodarczym, po dokonaniu koniecznej korekty, z uwagi na widoczne zagrożenia, szczególnie niebezpieczne dla strony amerykańskiej; w obszarze bezpieczeństwa ekologicznego, choć ten może stracić 
na znaczeniu po wyborze Donalda J. Trumpa 45 prezydentem Stanów Zjednoczonych Ameryki; obszarze politycznym - tam, gdzie strony będą dostrzegały wspólnotę interesów, przy jednoczesnym prowadzeniu cichej, wyrafinowanej rywalizacji w różnych obszarach współczesnego świata. Pewne jest, że od układu stosunków między „smokiem a jastrzębiem” zależeć będzie kształtujący się ład międzynarodowy, który - zdaniem wielu - zmierza ku dwubiegunowości.

\section{Bibliografia}

BIAŁOWĄS T., KĄKOL M., Wymiana handlowa Stanów Zjednoczonych z Chinami w latach 1978-2008, [w:] Militarne i gospodarcze determinanty państwowości azjatyckiej, J. Marszałek-Kawa (red.), Toruń 2010, s. 298-299.

CHINA investment monitor. Tracking Chinese investment in the U.S., http:// rhg.com/interactive/china-investment-monitor.

COOK M. T., Sustaining U.S.-China Cooperation in Clean Energy, Wilson Center, https://www.wilsoncenter.org/sites/default/files/US_China\%20 Cooperatin\%20in\%20Clean\%20Energy.pdf.

COX M., The USA, China and the rising Asia, [w:] U.S. Foreign Policy, M. Cox, D. Stokes (red.), New York 2012, s. 259-274.

DUMBAUGH K., China's Foreign Policy: What does it mean for U.S. global interests?, Congressional Research Service, Report for Congress, 08.07.2008.

DUMBAUGH K., China-U.S. Relations: Current Issues and Implications for U.S. Policy, Congressional Research Service, Report for Congress, 14.06.2006.

FOOT R., WALTER A., China, the United States, and Global Order, New York 2011.

FRIEDBERG A. L., The Future of U.S.-China Relations. Is Conflict Inevitable?, „International Security” 2005, nr 2, vol. 30.

HALIŻAK E., Stosunki amerykańsko-chińskie. Partnerzy czy rywale XXI wieku?, „Azja i Pacyfik” 2001, nr 4.

HENRY Kissinger o przyszłości stosunków amerykańsko-chińskich, http://www. usaeu.krakowskie.nazwa.pl/index.php?option=com_content\&view =article\&id=314:henry-kissinger-o-przyszoci-stosunkow-amerykaskochinskich\&catid=17:przegld\&Itemid=13.

HUASHOU M., Retrospekcje i perspektywy rozwoju stosunków pomiędzy ChRL a USA, [w:] Chiny supermocarstwem XXI wieku? Rozważania na temat polityki i gospodarki Państwa Środka, J. Marszałek-Kawa (red.), Toruń 2010. 
INDYK M. S., LIBERTHAL K. G., O'HANLON M. E., Zmieniając historię. Polityka zagraniczna Baracka Obamy, Warszawa 2013.

INTERNATIONAL Students in the United States, http://www.iie.org/Services/ Project-Atlas/United-States/International-Students-In-US\#.V0b38OSbIwA.

KOSMALA-KOZŁOWSKA M., Dwie cywilizacje. Dwa systemy wartości.

Dwie wizje praw człowieka, [w:] Jednostka i społeczeństwo w Azji Wschodniej, A. W. Jelonka (red.), Toruń 2007.

MELTZER J. P., U.S.-China Joint Presidential Statement on Climate Change:

The road to Paris and Beyond, http://www.brookings.edu/blogs/planetpolicy/posts/2015/09/29-us-china-statement-climate-change-meltzer.

MEN J., Sino-UE-U.S. relations: where are they going?, [w:] The UE, U.S. and China. Towards the new international order, J. Men, W. Shen (red.), Oxford 2010.

MORRISON W. M., China-U.S. trade issues, Congressional Research Center, Report for Congress, 15.12.2015.

PAN Y., VANHONACKER W. R., Chinese and American Cultures: Value Structure and Family Orientation. An Explorative Study, Euro-Asia Centre Research Series, September 1992.

PERO-FREEMAN S., FLEURANT A., WEZEMAN P. D., WEZEMAN S. T., Trends in World Military Expenditure, 2014, „SIPRI Fact Sheet” April 2015, http://books.sipri.org/files/FS/SIPRIFS1504.pdf.

QIXIANG Y., The United States, [w:] China's Foreign Trade, Z. Peiji, R. W. Huenemann (red.), Lantzville 1989.

ROLLINS J. W., U.S.-China Cyber Agreement, CRS Insight, 6.10.2015.

SAUNDERS P. C., To Rebalance to Asia: U.S.-China Relations and Regional Security, „Strategic Forum”, August 2013, nr 281.

SIMON S., 10 Characteristics of Chinese diplomacy in the Xi Jinping era, http://foreignpolicyblogs.com/2016/04/19/10-characteristics-of-chinesediplomacy-in-the-xi-jinping-era/.

STRENGTHENING U.S.-China Climate Change and Energy Engagement - Recommendations for Leaders and Policymakers in the U.S. and China, https://www.nrdc.org/sites/default/files/int_09021801a.pdf.

SZCZUDLIK-TATAR J., China's Response to the United States' Asia-Pacific Strategy, „Policy Paper”, October 2012, nr 41.

TOMASZEWSKI J., Zmiany w polityce bezpieczeństwa USA, „Bezpieczeństwo Narodowe" 2012, nr 3-4.

TOP ten trading partners of the China mainland, http://www.chinadaily.com. cn/bizchina/2014-02/19/content_17290565.htm. 
U.S. students studying overseas, http://www.iie.org/en/Services/Project-Atlas/ United-States/US-Students-Overseas\#.V0b4DuSbIwA.

U.S.-CHINA Joint Presidential Statement on Climate Change, https://www. whitehouse.gov/the-press-office/2015/09/25/us-china-joint-presidential -statement-climate-change.

WEI J., China-Chile FTA Talks Smooth, „Daily China”, 29.01.2005, http:// www.chinadaily.com.cn/english/doc/2005-01/29/content_413383.htm.

WILLIAMS B. R., DOLVEN B., FERGUSSON I. F., MANYIN M. E., MARTIN M. F., MORRISON W. M., The Trans-Pacific Partnership: Strategic Implications, Congressional Research Service, Report for Congress, 3.02.2016. 